\title{
Experimental studies on intra-abdominal adhesions
}

\author{
NOBORU IIJIMA \\ M.D. \\ KICHI INOUE \\ M.D.
}

\author{
TAKASHI YAMAMOTO \\ M.D. \\ FujIKo GomI \\ M.D.
}

\begin{abstract}
The Department of Surgical Research
of The Institute for Medical Science, The University of Tokyo, Japan
\end{abstract}

\section{Summary \\ Various intra-abdominal adhesions have been pro- duced in rats and mice. \\ Those animalsgiven an intra-peritoneal injection of pro- toporphyrin showed a reduction of adhesion formation. \\ Its mechanism has been discussed in view of Ellis's concept. \\ It seems to be appropriate to use PPN for patients} who may develop post-operative adhesions.

\section{Introduction}

How to prevent or reduce the incidence of intraperitoneal adhesions is one of the important problems in abdominal surgery. Adhesions of some kind develop in $70-90 \%$ of patients who have had laparotomies (Coletti \& Bossart, 1964). The high incidence of adhesions and their possible serious consequences make consideration of their prevention of practical importance.

Inflammatory reactions are observed in the peritoneum following mechanical damage. Serofibrinous exudation produces a fibrinous coat on the damaged surface. It is considered that such fibrinous coats may cause adhesions of surrounding serosal structures. However, the fundamental etiology of the fibrinous adhesions following abdominal surgery is still poorly known. Mechanical damage, infection (Williams, 1901), reperitonealization, thermal or chemical injuries and foreign bodies (Saxen \& Myllärniemi, 1968) have been discussed as causative factors of adhesions.

Recently, it was suggested by Ellis (1962) that the main factor producing postoperative intra-abdominal adhesions is tissue ischaemia. In other studies, it was found that protoporphyrin (PPN), a basic component of haemoglobin, can enter into the living cell and has an anti-anoxic action (Katto et al., 1965; Yamamoto, Iijima \& Katto, 1966).

The present study was designed to investigate whether PPN may prevent intra-abdominal adhesions by eliminating the 'tissue anoxia' that was postulated by Ellis. Zinc sulphate (Pories et al., 1967) reported as an effective agent in wound healing and dextran (Grosz et al., 1967) which inhibits intra-abdominal adhesions by mechanical separation between intestines and steroids were also investigated.

\section{Materials and methods}

Two hundred and sixty-eight Donryu and Wistar rats and 40 DDD mice of both sexes, weighing 200-300 g (rats) and 20-25 g (mice) were used as experimental animals.

\section{Experiment 1}

A total of forty-seven rats were anaesthetized with ether. Although strict asepsis was not obtained, the abdomen was shaved and the skin painted with iodine. After laparotomy was performed by midline incision, the mesentery of the small intestine was separated closely against the bowel wall from 1.9 to $2 \cdot 1 \mathrm{~cm}$ in length as in Ellis's (1962) experiment. These rats were divided into three groups. In the first group containing ten rats, a sheet of thin sterile polythene film was loosely wrapped around the intestinal segment of which the mesentery had been severed for a length of $2.0 \mathrm{~cm}$. In the second group of eighteen rats, PPN (200 mg in $1 \mathrm{ml})$ was injected intraperitoneally every day for 5 days. In the third group containing nineteen rats, the same volume of saline was injected as in the second group. All were submitted to autopsy 5 days post-operatively to examine the extent of adhesions.

\section{Experiment 2}

A total of seventy-three rats and eighty-one mice were anaesthetized with ether. At laparotomy a part of the right parietal peritoneum was picked up and an area of about $1.5 \mathrm{~cm}^{2}$ (in rats) and $0.8 \mathrm{~cm}^{2}$ (in mice) was excised. In twenty-five rats and twenty-four mice the peritoneal wounds were sutured with con- 
tinuous silk. In twelve rats and eighteen mice, they were massively ligated with silk. In twelve rats and twenty mice, the wounds were not sutured, but the silk was left hanging without a knot. On the next day, and the 3rd, 5th and 7th days after operation, each wound was carefully re-opened and examined for the presence of adhesion to the wounds in parietal peritoneum.

\section{Experiment 3}

A total of forty mice were anaesthetized and laparotomy was performed as described before. One part of the parietal peritoneum of each mouse was massively ligated. In the control group including ten mice $0.2 \mathrm{ml}$ of normal saline was injected intraperitoneally. The other thirty mice were divided into three groups. In the first group, ten mice were given $100 \mathrm{mg}$ of zinc-sulphamine-sulphate every day. In the second group, ten mice were given intraperitoneally $100 \mathrm{mg}$ of Predonin $3 \mathrm{hr}$ prior to laparotomy and in the third group ten mice were intraperitoneally injected with PPN (200 mg) every day for 3 days after operation. After 1 week the abdomen of each mouse was re-opened and a further exploration was made to know the extent of intraperitoneal adhesions as before. (Predonin = prednisolone-Na-succinate.)

\section{Experiment 4}

In a total of fifty-nine rats, the caecum was crushed by Pean's haemostat for $1 \mathrm{~min}$ to produce adhesions as shown in Grosz's experiment (Grosz et al., 1967). In twenty control rats, $1 \mathrm{ml}$ of saline was administered intraperitoneally. In seventeen rats and twenty rats, $1 \mathrm{ml}$ of dextran and $1 \mathrm{ml}$ of PPN $(200 \mathrm{mg}$ ) were intraperitoneally injected every other day for 6 days. After 1 week each wound was re-opened and examined as before.

\section{Experiment 5}

A $2 \mathrm{~cm}$ midline incision was made in eighty-nine rats. In sixty-nine rats the wounds were closed as follows: peritoneum with continuous 00 plain catgut, linea alba with continuous 00 chromic catgut and silk with 0 black silk interrupted. Sixty rats were divided into three groups. The first twenty rats were injected with PPN (200 mg) daily for 7 days. In the second twenty rats the peritoneum was not sutured and the linea alba and skin were closed as before. In the third twenty rats were used as control. After 1 week each wound was carefully re-opened and examined for the presence of adhesion to the wound. In the twenty-nine rats, if an adhesion was present it was carefully separated from the wound. Then, the wound made on the other part of an intact peritoneum was sutured as before. Sixteen out of twenty-nine rats were given single injection of PPN $(200 \mathrm{mg})$ immediately after re-operation and thirteen rats were served as control. One week later, the rats were killed and development of adhesion to the initial wound was investigated.

\section{Results}

\section{Experiment 1 (Table 1)}

In seven out of ten rats in whom the intestinal segment was wrapped around with polythene film, intestinal necrosis was observed $24 \mathrm{hr}$ after operation. The incidence of massive adhesions was $0 \%$ in PPN administered group and $73 \%$ in physiological saline injected group. On the other hand, the incidence of a single adhesion was $100 \%$ in the former and $0 \%$ in the latter.

\section{Experiment 2 (Tables 2 and 3)}

The incidence of adhesions 7 days post-operative appears most often in both rats and mice of which peritoneal wounds were sutured by massive ligation. It was 80 and $100 \%$ in rats and 71 or $100 \%$ in mice. These data differ remarkably from those in the peritoneum-unsutured group (26 and $20 \%$ ). The group of animals in which wounds were not sutured showed the least incidence of adhesions of 30 or $33 \%$ both in rats and mice. These results are in agreement with the experimental data shown by Ellis.

\section{Experiment 3 (Table 4)}

It was indicated that the healing process of peritoneum is different from that of skin (Cameron, Hassna \& De, 1957). The effect of zinc sulphate (reported as an effective agent in wound healing by Pories et al., 1967) was investigated. As shown in Table 4 the incidence of adhesions in the zincsulphamine-sulphate treated group and PPN group

TABLE 1. Extent of adhesions following mesenteric division in Donryu rats

\begin{tabular}{|c|c|c|c|c|c|}
\hline \multirow{2}{*}{ Treatment } & \multirow{2}{*}{$\begin{array}{l}\text { No. } \\
\text { of } \\
\text { rats }\end{array}$} & \multicolumn{2}{|c|}{ Massive adhesions } & \multicolumn{2}{|c|}{ Single adhesion } \\
\hline & & No./total & $\%$ & No./total & $\%$ \\
\hline $\begin{array}{l}\text { Control } \\
\text { Intestine was wrapped with film }\end{array}$ & $\begin{array}{l}19 \\
10\end{array}$ & \multicolumn{4}{|c|}{$\begin{array}{l}\text { Intestinal gangrene took place } \\
\text { in } 70 \%(7 / 10)\end{array}$} \\
\hline PPN & 18 & $0 / 18$ & 0 & $18 / 18$ & 100 \\
\hline
\end{tabular}


TABLE 2. Incidence of adhesion to peritoneal wounds in Donryu rats

\begin{tabular}{|c|c|c|c|c|c|}
\hline \multirow[b]{2}{*}{ Treatment } & \multirow[b]{2}{*}{$\begin{array}{l}\text { No. } \\
\text { of } \\
\text { rats }\end{array}$} & \multicolumn{4}{|c|}{ No. with adhesions } \\
\hline & & $\begin{array}{c}\text { After } \\
24 \mathrm{hr} \\
\text { (No./total) }\end{array}$ & $\begin{array}{c}\text { After } \\
3 \text { days } \\
\text { (No./total) }\end{array}$ & $\begin{array}{c}\text { After } \\
5 \text { days } \\
\text { (No./total) }\end{array}$ & $\begin{array}{c}\text { After } \\
7 \text { days } \\
\text { (No./total) }\end{array}$ \\
\hline $\begin{array}{l}\text { Peritoneum not sutured } \\
\text { Peritoneum sutured } \\
\text { Peritoneum ligation } \\
\text { Peritoneum not sutured } \\
\text { only hanging silk } \\
\text { without knot }\end{array}$ & $\begin{array}{l}24 \\
25 \\
12 \\
12\end{array}$ & $\begin{array}{l}4 / 5(80 \%) \\
5 / 5(100 \%) \\
3 / 3(100 \%) \\
0 / 4(0 \%)\end{array}$ & $\begin{array}{l}6 / 10(60 \%) \\
8 / 10(80 \%) \\
3 / 3(100 \%) \\
0 / 4(0 \%)\end{array}$ & $\begin{array}{l}2 / 5(40 \%) \\
4 / 5(80 \%) \\
2 / 3(66 \%) \\
0 / 4(0 \%)\end{array}$ & $\begin{array}{l}1 / 4(25 \%) \\
4 / 5(80 \%) \\
3 / 3(100 \%) \\
0 / 4(0 \%)\end{array}$ \\
\hline
\end{tabular}

TABLE 3. Incidence of adhesions to peritoneal wounds in DDD mice

\begin{tabular}{|c|c|c|c|c|c|}
\hline \multirow[b]{2}{*}{ Treatment } & \multirow[b]{2}{*}{$\begin{array}{l}\text { No. } \\
\text { of } \\
\text { rats }\end{array}$} & \multicolumn{4}{|c|}{ No. with adhesions } \\
\hline & & $\begin{array}{c}\text { After } \\
24 \mathrm{hr} \\
\text { (No./total) }\end{array}$ & $\begin{array}{c}\text { After } \\
3 \text { days } \\
\text { (No./total) }\end{array}$ & $\begin{array}{c}\text { After } \\
5 \text { days } \\
\text { (No./total) }\end{array}$ & $\begin{array}{c}\text { After } \\
7 \text { days } \\
\text { (No./total) }\end{array}$ \\
\hline $\begin{array}{l}\text { Peritoneum not sutured } \\
\text { Peritoneum sutured } \\
\text { Peritoneum ligation } \\
\text { Peritoneum not sutured } \\
\text { only hanging silk } \\
\text { without knot }\end{array}$ & $\begin{array}{l}18 \\
25 \\
18 \\
20\end{array}$ & $\begin{array}{l}4 / 5(80 \%) \\
6 / 6(100 \%) \\
4 / 4(100 \%) \\
0 / 4(0 \%)\end{array}$ & $\begin{array}{l}1 / 4(25 \%) \\
5 / 6(83 \%) \\
3 / 5(60 \%) \\
0 / 4(0 \%)\end{array}$ & $\begin{array}{l}1 / 4(25 \%) \\
3 / 6(50 \%) \\
4 / 4(100 \%) \\
2 / 6(33 \%)\end{array}$ & $\begin{array}{l}1 / 5(20 \%) \\
5 / 7(71 \%) \\
5 / 5(100 \%) \\
2 / 6(33 \%)\end{array}$ \\
\hline
\end{tabular}

TABLE 4. Incidence of adhesion following peritoneal litigation in DDD mice

\begin{tabular}{lccc}
\hline & No. of & \multicolumn{2}{c}{ With adhesions } \\
\cline { 3 - 4 } \multicolumn{1}{c}{ Treatment } & mice & No. & $\%$ \\
\hline Saline control & 10 & 10 & 100 \\
Zinc-sulphamine-sulphate & 10 & 10 & 100 \\
Predonin & 10 & 7 & 70 \\
PPN & 10 & 5 & 50 \\
\hline
\end{tabular}

was 100 and $50 \%$ in contrast to $100 \%$ in the controls. Zinc-sulphamine-sulphate did not prevent intraabdominal adhesions in this experiment.

\section{Experiment 4 (Table 5)}

It was reported that dextran (Grosz et al., 1967) can prevent post-operative adhesions. As shown, Table 5, ten out of twenty-two PPN-injected mice and nine out of seventeen mice given dextran developed adhesions. In a control group, adhesions were observed in seventeen out of twenty mice. Both dextran and PPN appear to prevent intra-abdominal adhesions equally.

\section{Experiment 5 (Table 6)}

After operation eleven out of twenty rats whose peritoneum had been sutured showed adhesions to the wound. The adhesion, comprising omentum, was easily separable from the wound. In both groups of twenty rats of which the peritoneum had not been sutured or had been sutured and injected with PPN, only five animals showed adhesions. After the second operation, only two out of sixteen rats developed adhesions to the sutured peritoneum (Fig. 1). On the contrary, nine out of thirteen control rats showed adhesions.

TABLE 5. Incidence of adhesions to pressed wounds in caecum of Donryu rats

\begin{tabular}{lccccc}
\hline Treatment & $\begin{array}{c}\text { No. } \\
\text { of } \\
\text { rats }\end{array}$ & \multicolumn{2}{c}{$\begin{array}{c}\text { Duration } \\
\text { of } \\
\text { pressing } \\
\text { (min) }\end{array}$} & \multicolumn{2}{c}{ No. with adhesions } \\
\cline { 4 - 6 } & 20 & 1 & No. & $\%$ \\
\hline Saline control & 17 & 1 & 17 & 85 \\
Dextran & 22 & 1 & 10 & 55 \\
PPN & 1 & & 10 & 45 \\
\hline
\end{tabular}

Dextran: clinical dextran $(1 \mathrm{ml})$ was injected i.p. every day.

PPN: $1 \mathrm{ml}(200 \mathrm{~g})$ was injected i.p. every other day. 
TABLE 6. Incidence of adhesions to laparotomy wounds in Wistar rats

\begin{tabular}{|c|c|c|c|c|c|c|}
\hline & \multicolumn{3}{|c|}{ One operation } & \multicolumn{3}{|c|}{ Two operations } \\
\hline & \multirow{2}{*}{$\begin{array}{l}\text { No. } \\
\text { of } \\
\text { rats }\end{array}$} & \multicolumn{2}{|c|}{$\begin{array}{c}\text { With } \\
\text { adhesions }\end{array}$} & \multirow{2}{*}{$\begin{array}{l}\text { No. } \\
\text { of } \\
\text { rats }\end{array}$} & \multicolumn{2}{|c|}{$\begin{array}{l}\text { With } \\
\text { adhesions }\end{array}$} \\
\hline & & No. & $\%$ & & No. & $\%$ \\
\hline $\begin{array}{l}\text { Peritoneum sutured } \\
\text { Peritoneum sutured }+ \text { PPN } \\
\text { Peritoneum not sutured }\end{array}$ & $\begin{array}{l}20 \\
20 \\
20\end{array}$ & $\begin{array}{r}11 \\
5 \\
5\end{array}$ & $\begin{array}{l}55 \\
25 \\
25\end{array}$ & $\begin{array}{l}13 \\
16\end{array}$ & $\begin{array}{l}9 \\
2\end{array}$ & $\begin{array}{l}69 \\
13\end{array}$ \\
\hline
\end{tabular}

TABLE 7. Influence of PPN on oxygen consumption of liver slices from mouse under various hypoxic conditions in vitro (average value in five times of experiments)

\begin{tabular}{|c|c|c|c|c|c|c|c|}
\hline \multirow{3}{*}{ Oxygen } & \multirow{3}{*}{$\frac{\text { Control }}{\mathrm{O}_{2} / \mathrm{mg}}$} & \multicolumn{6}{|c|}{ PPN added } \\
\hline & & \multicolumn{2}{|c|}{$60 \mu \mathrm{g} / \mathrm{ml}$} & \multicolumn{2}{|c|}{$30 \mu \mathrm{g} / \mathrm{ml}$} & \multicolumn{2}{|c|}{$10 \mu \mathrm{g} / \mathrm{ml}$} \\
\hline & & $\mathrm{O}_{2} / \mathrm{mg}$ & $+\%$ & $\mathrm{O}_{2} / \mathrm{mg}$ & $+\%$ & $\mathrm{O}_{2} / \mathrm{mg}$ & $+\%$ \\
\hline $\begin{array}{r}100 \% \\
20 \% \\
10 \% \\
5 \%\end{array}$ & $\begin{array}{r}11 \cdot 8 \\
6 \cdot 4 \\
3 \cdot 6 \\
2 \cdot 2\end{array}$ & $\begin{array}{r}11 \cdot 8 \\
7 \cdot 4 \\
4 \cdot 2 \\
2 \cdot 8\end{array}$ & $\begin{array}{r}0 \\
+19 \\
+17 \\
+27\end{array}$ & $\begin{array}{r}11 \cdot 8 \\
7 \cdot 4 \\
4 \cdot 2 \\
2 \cdot 6\end{array}$ & $\begin{array}{r}0 \\
+19 \\
+17 \\
+18\end{array}$ & $\begin{array}{r}11 \cdot 8 \\
6 \cdot 5 \\
3 \cdot 7 \\
2 \cdot 2\end{array}$ & $\begin{array}{l}0 \\
0 \\
0 \\
0\end{array}$ \\
\hline
\end{tabular}

$\mathrm{O}_{2}$ consumption per $\mathrm{mg}$ of dry weight of liver in DDD mice.

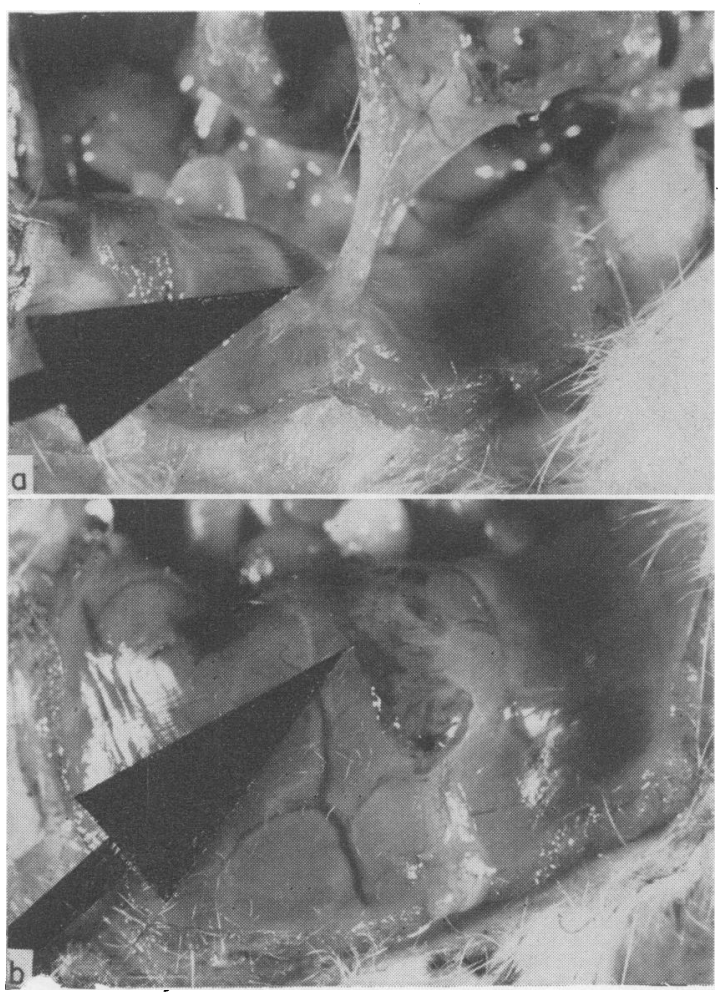

FIG. 1. (a) Intra-abdominal adhesion following laparotomy in Experiment 5. (b) Accumulation of PPN in the damaged peritoneal surface without adhesion in Experiment 5.

\section{Discussion}

Numerous clinical and experimental studies have been made of attempts to prevent or diminish the incidence of intra-abdominal adhesions. Various agents such as heparin (Lehman \& Boys, 1940), corticosteroids (Eskeland, 1963), fibrinolysin (Jewett et al., 1965) have been adopted for prevention of adhesions. However, they were useless or are no longer used post-operatively because of their dangerous side-effects.

Recently, Ellis (1962) has postulated a new concept-that the aetiological factor in adhesion formation is 'tissue ischaemia'. $70 \%$ of mice whose intestines were wrapped with polythene film developed gangrene of an intestinal segment by $24 \mathrm{hr}$ as shown in Table 1. This suggests that intraabdominal adhesions may be a biological adaptation, a compensatory mechanism by the host to supply oxygen-saturated blood to the damaged area as suggested by Ellis (1962).

As shown in Tables 2 and 3, intra-abdominal wounds which were closed without suturing the peritoneal defect showed a lower incidence of adhesions than those closed by suturing. This suggests that anoxia may inhibit the natural process of peritoneal healing. At this point it is interesting to note the fact that in a hypoxic condition the partially hepatectomized rat showed a delay in the initiation of mitosis (Tararico, Feller \& Neville, 1969).

The aetiology of post-operative adhesions has not yet been clarified. The different influences in post- 
TABLE 8. Influence of PPN on serum $\beta$-glucuronidase and acid phosphatase of DDD mouse in endotoxin shock

\begin{tabular}{|c|c|c|c|c|c|c|c|c|}
\hline \multirow{2}{*}{ Enzyme activity } & \multicolumn{2}{|c|}{ Control } & \multicolumn{2}{|c|}{ Endotoxin } & \multicolumn{2}{|c|}{$\begin{array}{c}\text { Endotoxin } \\
+ \\
\text { PPN }\end{array}$} & \multicolumn{2}{|c|}{$\begin{array}{c}\text { Endotoxin } \\
+ \\
\text { Predonin }\end{array}$} \\
\hline & $\mathrm{U} / \mathrm{mg}$ & $+\%$ & $\mathrm{U} / \mathrm{mg}$ & $+\%$ & $\mathrm{U} / \mathrm{mg}$ & $+\%$ & $\mathrm{U} / \mathrm{mg}$ & $+\%$ \\
\hline $\begin{array}{l}\text { B-Glucuronidase } \\
\text { Acid phosphatase }\end{array}$ & $\begin{array}{l}1 \cdot 6 \\
3 \cdot 2\end{array}$ & & $\begin{array}{l}2 \cdot 7 \\
4 \cdot 9\end{array}$ & $\begin{array}{l}70 \\
53\end{array}$ & $\begin{array}{l}1 \cdot 8 \\
3 \cdot 6\end{array}$ & $\begin{array}{l}+12 \\
+12\end{array}$ & $\begin{array}{l}1 \cdot 7 \\
3.6\end{array}$ & $\begin{array}{l}+6 \\
+12\end{array}$ \\
\hline
\end{tabular}

PPN (200 g), Predonin (1 mg) were injected intraperitoneally immediately after the administration of endotoxin. $\beta$-Glucuronidase was measured $1 \mathrm{hr}$ and acid phosphatase was measured $2 \mathrm{hr}$ after peritoneal injection of $S h$.

Flexner endotoxin $\left(\mathrm{LD}_{50}\right)$. The average value of ten mice.

operative adhesion formation of anoxia and trauma are too difficult to evaluate. However, it was indicated in separate papers that PPN can, to some extent, not only restore the oxygen consumption of liver slices in vitro (Table 7), but also prevent the increase of $\beta$-glucuronidase and acid phosphatase in the serum of the endotoxin-shocked mouse (Table 8). $\beta$ Glucuronidase and acid phosphatase are thought to be lysosomal enzymes and under hypoxic conditions their increase in serum is generally accepted. Accordingly, these facts, in addition to various experimental results already reported (Yamamoto et al., 1966), suggest that PPN has an anti-anoxic effect. Moreover, Fig. 1 (a) and (b) shows that PPN accumulates in the traumatized area.

According to Ellis' concept, the effect of PPN as adhesion-preventing agent may be due to its antianoxic action on the damaged surface.

\section{Acknowledgment}

We wish to express our gratitude to Professor Yukio Ishibashi for his encouragement and generous advice in the present study.

\section{References}

Cameron, G.R., Hassna, S.M. \& De, S.N. (1957) Repair of Glisson's capsule after tangential wounds of the liver. Journal of Pathology and Bacteriology, 73, 1.
Coletti, L. \& Bossart, P.A. (1964) Intestinal obstruction during the early postoperative period. Archives of Surgery, 88, 774.

Ellis, H. (1962) The aetiology of post-operative abdominal adhesions. British Journal of Surgery, 50, 10.

Eskeland, G. (1963) Prevention of experimental adhesions in the rat by intraperitoneally administered corticosteroids. Acta chirurgica Scandinavica, 125, 91.

Grosz, C., Aka, E., Zimmer, J. \& Alterwein, R. (1967) The effects of intraperitoneal fluids on the prevention of experimental adhesions. Surgery, 60, 1232.

Jewetr, T.C., Ambrus, S.L., Ambrus, C.M. \& Mink, I.B. (1965) Effects of fibrinolytic enzymes on experimentally induced peritoneal adhesions. Surgery, 57, 280.

Katto, I., Matsuzawa, A., Gotoo, N., Iuima, N. \& Yamoмото, T. (1965) Medicine and Biology, 71, 277.

Lehman, E.P. \& Boys, F. (1940) The prevention of peritoneal adhesions with heparin. Annals of Surgery, 111, 427.

Pories, W.J., Henzel, J.H., RoB, C.G. \& Strain, W.H. (1967) Acceleration of wound healing in man with zinc sulphate given by mouth. Lancet, i, 121 .

SAXén, L. \& MYlläRniemi, H. (1968) Foreign material and postoperative adhesions. New England Journal of Medicine, 279, 200.

Talarico, K.S., Feller, D.D. \& Neville, E.D. (1969) Effects of hyperoxia and hypoxia on mitosis in the normal and regenerating rat liver. Proceedings of the Society for Experimental Biology and Medicine, 131, 430.

Williams, D.C. (1901) American Journal of Obstetrics, 43, 753.

Yамамото, T., IIJima, N. \& KАтto, I. (1966) Medicine and Biology, 74, 211. 